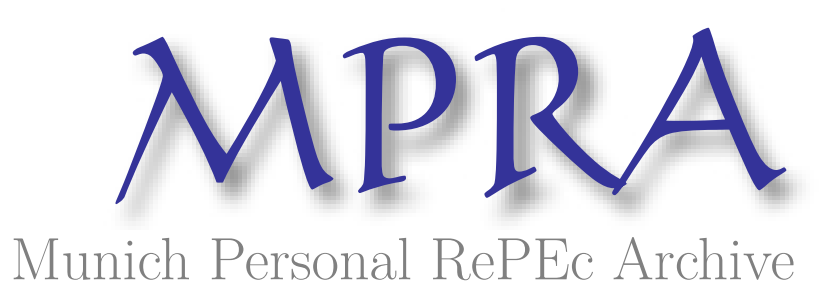

\title{
Firm Registration and Bribes: Results from a Microenterprise Survey in Africa
}

Clarke, George R.G.

Texas AM International University

25 June 2011

Online at https://mpra.ub.uni-muenchen.de/31857/

MPRA Paper No. 31857, posted 27 Jun 2011 01:04 UTC 


\title{
FIRM REGISTRATION AND BRIBES:
}

\section{RESULTS FROM A MICROENTERPRISE SURVEY IN AFRICA}

\author{
George R.G. Clarke*
}

June 2011

\author{
Division of International Banking and Finance Studies \\ A.R. Sanchez, Jr. School of Business \\ Texas A\&M International University
}

\footnotetext{
* The data used in this paper are from the Zambia Business Survey, which was collected for the World Bank, FinMark Trust-Zambia, and Zambia Business Forum. I would like to thank W. Marie Sheppard, Manju Shah and participants at the Public Choice Society meetings and a seminar at Texas A\&M International University for helpful comments. Responsibility for all errors, omissions, and opinions rests solely with the author.

Associate Professor, Division of International Banking and Finance Studies, Sanchez School of Business, Texas A\&M International University, 5201 University Boulevard, Laredo, Texas 78041. E-mail: GEORGE@GRGCLARKE.COM.
} 


\title{
FIRM REGISTRATION AND BRIBES:
}

\section{RESULTS FROM A MICROENTERPRISE SURVEY IN AFRICA}

\begin{abstract}
If corrupt bureaucrats target registered firms, then corruption may discourage registration. Using data from a survey of 4,801 microenterprises in Zambia, this paper looks at whether corruption is a more or less serious problem for registered firms. The paper finds results consistent with the cross-country evidence-registered firms appear to be more concerned about corruption than unregistered firms. This suggests that remaining informal and out-of-sight might reduce the burden of corruption. The paper also looks at two possible reasons why registered firms might be more concerned about corruption. It finds that there is little evidence that government officials specifically target registered firms. Registered firms were more likely to be involved in transactions with government or parastatal officials that could involve bribespossibly explaining why they are more concerned about corruption than other firms are-but they were no more likely to pay bribes during these transactions.
\end{abstract}

Keywords: Zambia; Africa; Corruption; Informality; Bribes.

JEL Codes: K42; D73; O17; E26. 


\section{Introduction}

Informality is a serious problem in many developing countries. ${ }^{1}$ It undermines government's ability to meet social goals through spending and regulation. It also poses a problem for formal firms that pay their taxes and comply with government regulations - informal firms that avoid these have a cost advantage over formal firms. But being informal can also cause problems for informal firms. Because informal enterprises do not have access to the formal legal protections and because it difficult for them to get outside resources for investment, they can find it difficult to grow and realize economics of scale. ${ }^{2}$

One of the many concerns about corruption is that it might contribute to informality. Firms might remain informal — and out-of-sight — to hide from corrupt officials. The crosscountry evidence is consistent with this-developing countries where informality is common tend to be more highly corrupt (Buehn and Schneider, forthcoming; Dreher and Schneider, 2010; Friedman and others, 2000; May and others, 2002).

Petty corruption might encourage firms to remain unregistered in several ways. The most direct is by increasing the time and cost associated with registering. When bureaucrats demand bribes to register enterprises, this will discourage registration. But petty corruption might also indirectly discourage firms from registering. If becoming formal makes firms more visible to the authorities, then it could expose them to bribe demands from bureaucrats not involved in the registration process. Remaining out-of-sight might protect against 'predatory behavior by government officials seeking bribes from anyone with officially registered economic behavior' (Johnson and others, 2000, p. 496). Being formal might also signal that the firm is more profitable and more able to pay bribes. If this is the case, corrupt government officials might be more likely to demand bribes, or might demand higher bribes, from registered firms.

Although this is true, other things might make formal firms less, not more, vulnerable to bribe demands. Firms that are not registered or that do not comply with tax and regulatory requirements might have to pay bribes to avoid punishment if they are caught. Moreover,

\footnotetext{
${ }^{1}$ See Schneider and Enste (2000) for a survey of the causes and consequences of informality.

${ }^{2}$ See, for example, discussions in de Soto (1988) or World Bank (2003). To open a small business account or get a loan at Barclays bank in Zambia, the MSME needs to be formally registered (Melzer and others, 2009) .
} 
managers of unregistered firms might be less willing to report corrupt officials or seek legal protection against bribe demands if they are concerned that getting involved with the authorities might lead to problems because they are unregistered. Because of this, corrupt officials might be more willing to demand bribes from managers of informal firms.

Rather than using macroeconomic data, this paper uses data from a survey of micro and small enterprises (MSEs) in Zambia to look at the interaction between informality and corruption. This allows us to more easily assess how formalization affects the degree to which firms within a particular institutional environment are affected by petty corruption and to identify possible reasons for this. We classify MSEs as informal if they are not registered with various government agencies. At the enterprise level, this seems to be the most natural way to identify informal firms. Moreover, given than less than one in twenty MSEs are registered with any government agency in Zambia, this definition should capture much informality.

Consistent with the macroeconomic evidence, we find that registered firms are more concerned about corruption than unregistered firms. In part, this might be because registered micro and small enterprises are more visible-larger, more capital intensive, and more urban. After controlling for differences along these dimensions, the gap in views about corruption become smaller.

But differences in observable characteristics of registered and unregistered firms do not fully explain the difference in perceptions - even after controlling for this, firms that are registered for taxes appear to be more concerned about corruption than other firms. We therefore look at two possible explanations for the greater concern expressed by managers of registered enterprises: (i) whether corrupt officials target registered firms for bribes during specific transactions - perhaps because they are more visible or better performing; and (ii) whether registered firms are more likely to be involved in transactions with corrupt officials.

The empirical analysis supports the second, but not the first, explanation. Registered enterprises are no more likely to have bribes requested during their transactions with government officials than unregistered firms. But they are more likely to engage in these transactions. This suggests that firms that are registered for taxes might be more concerned about corruption because they interact more with government officials rather than government officials demand 
more bribes from registered enterprises during specific transactions. Since several of these transactions are voluntary, and all are unrelated to registration, it is possible that these enterprises have more transactions because are more likely to need things such as utility connections rather than that corrupt officials target registered enterprises specifically.

\section{Corruption and firm registration in low-income countries}

Petty corruption can affect registered and unregistered firms differently. This section discusses ways that corruption might affect registered and unregistered firms and the empirical evidence from country-level and microeconomic studies.

\section{Relationship between petty corruption and informality}

Petty corruption could affect the cost of registration in several ways. Some costs fall disproportionately on registered, formal firms, while others will fall mostly on unregistered and informal firms. One useful distinction, proposed by Mendez and Sepulveda (2007), is the distinction between permit costs (bribery) and ticket costs (extortion).

Permit costs are the costs associated with getting permission to legally operate in a country. These costs can be substantial for firms in developing countries. De Soto (1988), for example, notes that when his team of Instituto Libertad y Democracia (ILD) researchers attempted to set up a garment factory in Peru, officials requested bribes ten times during the registration process. Since unregistered firms do not have permission to legally operate, permit costs fall mostly on registered firms.

Broadly speaking, petty corruption could affect the cost of getting needed permits or services in at least three ways. One way is that firms might need to pay bribes to get needed permits even though they have completed all legal requirements. Government bureaucrats might invent fictitious requirements, might 'lose' needed paperwork, or might simply refuse to process documents. In the absence of a non-corrupt appeals body (e.g., judiciary, non-corrupt management of the bureaucracy, or a government watchdog), firm owners might have little recourse in these instances other than paying requested bribes. Although the original goal of De Soto's (1988) research was to setup the factory without paying any bribes, the ILD researchers had to pay bribes in two of ten occasions where bribes were requested to be able to continue with 
the process of setting up a business even though they had completed all necessary legal requirements. By not registering, informal firms avoid these costs.

A second way that corruption might affect the cost of getting needed permits or services is 'speed money'. The time required to start a business and to complete other bureaucratic procedures can be quite high in many countries_-see, for example, World Bank (2003). Paying bribes to have paperwork processed more quickly reduces these costs for firms that register. Although bribes paid to speed up the process might improve efficiency — and are presumably less than the cost of the delay that would be incurred otherwise - they fall only on formal firms that get the permits or licenses.

A final way that corruption might affect the cost of getting needed permits is when firm owners pay bribes to government officials to avoid having to comply with needed regulations. For example, a firm owner might pay a bribe to a regulator to allow him to register without actually complying with all requirements. Although paying the bribe is presumably less than the cost of complying with the requirement, the costs will fall disproportionately on firm that register (i.e., formal firms). Firms that do not register do not have to either comply with registration requirements or pay bribes to avoid doing so.

In addition to avoiding bribes directly associated with getting permission to operate, unregistered firms might be able to avoid bribes outside of the registration process. Registering with the government makes firms more visible to government officials and so might also result in additional bribe demands. For example, informal firms that do not register with the tax authorities, avoid routine tax inspection and so avoid paying bribes during these inspections. Even when formal firms are complying with tax requirements, it might be easier in some cases to pay bribes to tax inspectors that invent fictitious requirements rather than bear the costs and uncertainty of trying to appeal decisions. ${ }^{3}$ Moreover, informal firm that are operating illegally, have less incentive to get permits or licenses unrelated to registration.

\footnotetext{
3 The 2004 Investment Climate Assessment for Zambia noted that firms reported that the Zambia Revenue Authority's behavior was 'arbitrary and punitive' (Regional Program on Enterprise Development, 2004). It also noted that the burden of proof regarding appeals and penalties was on the firm
} 
This is not to say that informal firms can avoid all permit costs. Even informal firms need some government services. For example, many informal firms would benefit from public utility connections and bribes are often needed to get these. ${ }^{4}$ Similarly, even if they choose not to become fully formal, they might need to get some local permits or licenses (e.g., to operate in a market place) to avoid harassment from local authorities.

But permit costs are not the only costs associated with petty corruption. A second set of costs are 'ticket costs'. These are the costs of paying bribes to government officials if the firm is caught not complying with regulations or other government rules. For example, if a police officer catches a street trader operating illegally (i.e., without all needed permits), the officer might demand, or the street trader might offer, a bribe to avoid arrest or the confiscation of goods. Similarly, a firm that is not registered for taxes might pay bribe tax inspectors to encourage them to look the other way.

Although ticket costs probably fall primarily on informal firms, this does not mean that ticket costs are zero for registered firms. First, even formal, registered firms do not necessarily comply with all regulatory requirements. In the World Bank's 2003 Enterprise Survey for Zambia, less than half of the formal firms in the survey reported that they believed that 'firms like theirs' reported all revenues to the tax authorities. ${ }^{5}$ Second, even complying with all regulations, does not ensure that corrupt officials will not demand bribes for fictitious or minor violations of the law. ${ }^{6}$ Moreover, in some case, it might be easier to pay a bribe rather than to fight the charges.

Registered firm might also face higher ticket costs than unregistered firms for an additional reason - they are more visible and better performing that unregistered firms (see Table 1). Bureaucrats wanting bribe payments will probably find it easier to locate registered firms and might demand higher payments from them if they believe that registered firms have greater

\footnotetext{
${ }^{4}$ See, for example, Clarke and Xu (2004) or Gonzalez and others (2007)

5 Authors' calculations using data from the 2003 World Bank Enterprise Survey. The sample only included firms registered with the Zambia Revenue Authority (Regional Program on Enterprise Development, 2004).

${ }^{6}$ For example, Easterly (2002) describes his experience of being pulled over by a police officer in Mexico City and being accused of the crime of 'transporting books without a license'. He avoided being taken to the station by offering to pay a fine on the spot.
} 
ability to pay bribes. Larger, more capital intensive, and urban firms will be more visible to bureaucrats demanding bribes - and will probably appear to be more able to pay bribesirrespective of registration status. Moreover, they are probably more likely to register because they are more visible. If registering increases either visibility or perceptions about ability to pay, registration might increase the amount that firms have to pay in bribes.

In summary, it is not immediately clear whether corruption will encourage or discourage registration. On the one hand, permit costs are likely to be higher for registered firms than for unregistered firms. On the other, ticket costs might be higher for unregistered firms. Because corruption is only one of the many things that affect registration decisions, observing registration decisions does not tell us whether corruption encourages or discourages registration. One of the goals of this paper is to try to assess whether registered or unregistered firms are more affected by corruption.

\section{Empirical Evidence}

Previous studies have linked informality with corruption using country-level data. Using data from Latin America, the OECD, and Europe and Central Asia, Friedman and others (2000) find that countries that scored one point worse on Political Risk Services corruption indexroughly the difference between Zambia and Ghana-had informal sectors that were about 10 percentage points larger than similar countries that scored one point better. Similarly, May and others (2002) show that corruption is correlated with unofficial activity in both transition and non-transition economies. Buehn and Schneider (forthcoming) find similar results using a structural model. And Dreher and Schneider (2010) find a positive association between corruption and informality in low-income but not high-income countries. ${ }^{7}$

Several microeconomic studies have also looked at the relationship between corruption and informality. By focusing on unregistered firms, this study differs from most previous microeconomic studies, which have focused on firms that are partly or mostly formal. In an important study, Johnson and others (2000) use a measure of informality related to tax evasion-

\footnotetext{
7 The results in Dreher and Schneider (2010) are not strongly robust. They do not find an association between corruption and informality for either high or low income countries for one of two measures of corruption.
} 
the percent of sales that the firm hides from the tax authorities. ${ }^{8}$ They find that firms that report paying bribes report less of their sales to the authorities. They interpret this result to suggest that either "firms hide more to avoid corruption" or "firms that hide more have to make illegal payments" (p. 515). Similarly, Svensson (2003) uses principal component analysis to show that firms in Uganda that report paying their taxes, have utility connections, and trade across borders are more likely to report paying bribes than other firms. They did not, however, pay more in bribes than other firms.

\section{Data}

The data used in this paper comes from the Zambia Business Survey. The survey covered 4,801 micro and small enterprises (MSEs), which are defined as businesses with 50 or fewer employees, in urban and rural areas. The sample was selected through rigorous area sampling, with the 2000 population census used as the sampling frame. ${ }^{9}$ This methodology ensures that both registered and unregistered firms are included in the sample.

The firms in the survey are small. Including the owners, the average firm had less than five workers (see Table 1). About one-third of the firms had no employees other than the owner and only about 10 percent of firms had over 10 employees. About four-fifths of the sample was located in rural areas. Most of the firms were either farms (about 70 percent) or traders (about 22 percent). There were a small number of manufacturing firms (about 3 percent of the sample) and other service firms such as hotels and restaurants, construction firms, and repair shops (about 4 percent).

\section{Firm Registration}

Studies of the informal economy usually define informality as economic activities that are not measured or visible to the Government. For example, Schneider and Klinglmair (2004) note several related definitions including the following:

Smith (1994, p.18) defines [the informal economy] as 'market-based production of goods and services, whether legal or illegal that escapes detection in the official

\footnotetext{
${ }^{8}$ Johnson and others (2000), in fact, explicitly note that their sample excludes fully unregistered enterprises.

${ }^{9}$ See Clarke and others (2010) for a detailed description of the survey.
} 
estimates of GDP.' Or to put it another way, one of the broadest definitions of [the informal economy], includes those economic activities and the income derived from them that circumvent or otherwise avoid government regulation, taxation, or observation.'

Similarly, Schneider (2005) defines informality as

[All] market-based legal production of goods and services that are deliberately concealed from public authorities for the following reasons:

(1) to avoid payment of income, value added or other taxes,

(2) to avoid payment of social security contributions,

(3) to avoid having to meet certain legal labor market standards, such as minimum wages, maximum working hours, safety standards, etc., and

(4) to avoid complying with certain administrative procedures, such as completing statistical questionnaires or other administrative forms.

These definitions focus on activities, rather than firms. For example, goods produced by unregistered temporary workers that the firm paid under the table to avoid paying social security taxes would be classified as 'informal' even if the firm was registered with the business registrar, the firm paid corporate income taxes on all or most of its income and the firm complied with labor regulations for its permanent workforce. ${ }^{10}$

Although definitions based upon activities are useful when thinking about informality at the macroeconomic level, a more natural way to think about informality when using firm-level data is to define informality based upon firm registration. This seems appropriate given that most micro and small enterprises (MSEs) are not registered with any government agency. Although they might comply with some regulations or pay some required fees or local taxes, these unregistered firms are not complying with all requirements and, in practice, will mostly operate underneath the official purview of the authorities.

This is done by focusing on three question about company registration: (i) whether they are registered with the Patents and Company Registrar (PACRO) or other government institution responsible for commercial registration; (ii) whether the firm has an operating, trade or other business license with any local government institutions; and (iii) whether the firm has a taxpayer identification number (TPIN) from the Zambia Revenue Authority (ZRA). Throughout the

\footnotetext{
${ }^{10}$ Some definitions focus on workers rather than activities. See, for example, Perry and others (2006).
} 
paper, these questions are used to identify 'registered' or 'formal' enterprises. Firms that have done any of these things will be more visible to government officials.

Sole proprietorships, partnerships, or limited liability companies are required to register with PACRO unless they are sole proprietorships operating under the personal name of their owner. Sole proprietorships that are operating under a trade name are required to register as a business name under Section 3 of the Registration of Business Act Cap 389, while limited liability companies are required to register as companies under the Companies Act Cap $388 .{ }^{11}$ Because firms can operate under the personal name of their owner, however, firms could still operate legally without registering with PACRO.

Firms will also often have to get operating or trading licenses from - and pay license fees to-municipal or local governments. Requirements and fees will depend upon sector of operations, size of the firm, and locality. ${ }^{12}$ Some types of firms need to pay multiple fees and obtain multiple licenses. ${ }^{13}$

As well as registering with PACRO, businesses are also required to get a TPIN from the Zambia Revenue Authority. This applies to companies registered with PACRO under the Registration of Businesses Act and the Companies Act and to individuals operating businesses that are not registered as firms. ${ }^{14}$ After getting a TPIN, most of the firms (over 99 percent) appear to be too small to have to register for either the value-added tax or the income tax, both of which apply only to firms with turnover of more than K200 million (about $\$ 53,000$ at the

\footnotetext{
${ }^{11}$ Patents and Companies Registration Office (2009a; 2009b)

${ }^{12}$ Firms in many sectors including manufacturing, retail trade, and tourism need licenses from local municipalities (United Nations Conference on Trade and Development, 2003; Zambia Development Agency, 2009). See also Times of Zambia (2008) and ACT Watch (2009). Foreign Investment Advisory Service (2004a) provides a list of license fees for Lusaka in 2004. During field interviews in the fall of 2007 with small retail traders in Lusaka, most claimed that they had local licenses.

${ }^{13}$ In some sectors, firms need multiple licenses (Economics Association of Zambia, 2009). Foreign Investment Advisory Service (2004b) noted that some businesses need as many as 54 separate licenses from national, regional and local departments to operate.

${ }^{14}$ Zambia Revenue Authority (2009a)
} 
average exchange rate for 2008). These firms are, however, required to register to pay a presumptive three percent tax on turnover. ${ }^{15}$

Only about one in 20 of the firms in the sample reported that they were registered with any of the three agencies. They were most likely to report that they had an operating or trading license from a local or municipal government (about 1 in 20 MSMEs). Fewer reported that they were registered with PACRO (only about 1 in 30) or had a TPIN from the Zambia Revenue Authority (only about 1 in 50). Appendix 1 compares registration rates for the mostly microenterprises in the MSME survey with registration rates observed in surveys of larger and more sophisticated firms in Zambia.

\section{Corruption}

The survey asks several questions about corruption. One important question is "Do you think that [corruption] presents no obstacle, a minor obstacle, a moderate obstacle, a major obstacle, or a very severe obstacle to the current operations of the business." Corruption is one of 15 constraints that the survey asks about. Others include tax rates, access to finance, the macroeconomic environment and crime.

The second set of questions on corruption relate to whether bribes were requested during a set of transactions. The questions read: "Was a gift or informal payment asked for or expected to obtain [a landline telephone, electrical connection or water connection]. An additional question was asked about bribe requests during tax inspections - "In any of these [tax inspections or meetings with tax officials] was a gift or informal payment expected/requested".

\section{Characteristics of registered and unregistered firms}

Registered firms were slightly larger than unregistered firms (about 5.3 employees on average for registered firms compared with about 4.5 employees for unregistered firms). They were also more likely to be growing (32 percent compared with 26 percent) and were far more likely to be located in urban areas (about 61 percent of registered firms compared with 16 percent of unregistered firms). Agricultural firms made up a smaller share of registered firms

\footnotetext{
15 The turnover tax was introduced for MSMEs in 2004 (Zambia Revenue Authority, 2004). Firms with paid employees should also register for PAYE (Zambia Revenue Authority, 2009b)
} 
(about 30 percent compared with about 73 percent of unregistered firms), while other sectors made up correspondingly larger shares.

Overall, this suggests that registered firms are more visible to regulators than unregistered firms. On average, they are larger, are more likely to be located in urban areas, and are more likely to be expanding than unregistered firms are. After controlling for other factors (e.g., size, sector and location), capital intensive firms also appear to be more likely to be registered than less capital intensive firms - consistent with the idea that registered firms tend to be more visible and sophisticated than unregistered MSMEs. The coefficient on firm age is statistically insignificant suggesting that there is little difference between registered and unregistered firms in this respect after controlling for other factors.

\section{Econometric Results}

The first question that we look at is whether managers of registered firms see corruption as a greater or lesser problem than managers of unregistered firms. If corruption is a greater problem for registered firms, it might discourage firms from registration. After looking at whether the perceptions of managers or registered and unregistered firms differ, we try to assess reasons for the difference in perceptions. One possibility is that bureaucrats might target registered firms for bribes during specific transactions-perhaps because registered firms are better performing than unregistered firms. To see whether this is the case, we look at whether registered firms are more or less likely to report that bribes were demanded during specific transactions (getting a water connection, getting a power connection and during tax inspections). A second possibility is that registered firms might more frequently engage in transactions with

government officials We therefore look at whether registered firm engage in the specific transactions listed above.

Methodology: Impact of firm characteristics on views about corruption.

The question of how registration affects firm's perceptions about corruption is examined by estimating different versions of the equation below:

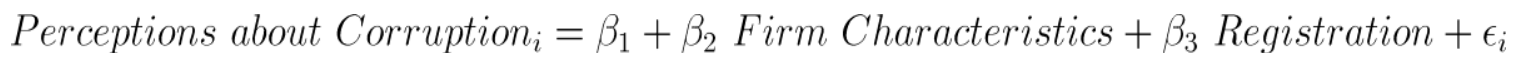


The dependent variable is an index variable ranking how great an obstacle the firm manager says corruption is. The firm characteristics are: (i) firm size (number of workers, linear and quadratic terms); (ii) age of the firm; (iii) a dummy variable indicating that the firm is growing; (iv) a dummy variable indicating that the firm is located in an urban area; (iv) an index variable indicating how capital intensive the firm is and (v) a series of sector dummies (agriculture, manufacturing, retail trade, and other services). These variables have been related to corruption in previous studies. ${ }^{16}$ The error term is assumed to be normally distributed. Because the dependent variable is an ordered index variable, the model is estimated using standard maximum likelihood estimation (i.e., ordered probit). Results from the regressions are shown in Table 2.

\section{Empirical Results}

Registration. As a first exercise, a dummy variable indicating whether the firm has registered with PACRO, obtained a TPIN, or obtained an operating license from local government institutions is included by itself in the ordered probit regression (see column 1 of Table 2). Based upon the point estimate of the coefficients, firms that are registered are about 7 percentage points more likely to say the corruption is a major or very severe obstacle than firms that are not registered. ${ }^{17}$ When the three separate dummy variables indicating registration with each agency are included one at a time, the coefficient on each variable is statistically significant at conventional significance levels. ${ }^{18}$

When the three separate dummy variables are included at the same time, the only coefficient that is statistically significant at conventional significance levels is the coefficient on the variable indicating that the firm has a TPIN. Firms that have a TPIN were about 16

${ }^{16}$ Gaviria (2002) finds a negative relationship between firms that report paying bribes and firms size for firms in Latin America. In contrast, Svensson (2003) and Safavian and others (2001) find a positive, but statistically insignificant relationship between firm size and probability of making bribe payments and perceptions about corruption respectively. For firm growth, Safavian and others (2001) find that firms in Russia that were growing more quickly are more likely to say that corruption is a problem than slower growing firms. Clarke and Xu (2004), however, do not find a statistically significant relationship between sales growth and bribe payments for Eastern Europe and Central Asia. Svensson (2003) finds that capital intensive firms pay more in bribes than other firms.

${ }^{17}$ Marginal effects are calculated by working out the marginal effect of switching the dummy variable from zero to one at the average value of all other variables.

${ }^{18}$ Results available upon request. 
percentage points more likely to say that corruption was a major or very severe obstacle than firms that did not. The coefficients on the variables indicating that the firm has registered with PACRO and that it has an operating license are small and statistically insignificant.

Other firm characteristics. As discussed previously, registered firms tend to be larger, more capital intensive, more likely to be located in urban areas, and faster growing. Because of this, registered firms are more visible and because they are more capital intensive (that is their sunk costs are higher) they might appear to bribe takers to be attractive with respect to bribe demands. Because these factors might affect bribes independently of registration status, Columns 3-4 include these additional control variables.

The results suggest that larger, more visible firms are more likely to say that corruption is a serious problem than other firms. Large firms and firms in urban areas are more likely to say that corruption is a serious problem (see columns 3-4 in Table 2). In addition, more capital intensive firms are more likely to say that corruption is a problem. These firms will presumably find it harder to hide from the authorities and to switch or shut down operations when facing excessive bribe demands (i.e., they have fewer sunk costs). This is consistent with results in Svensson (2003).

Including these variables makes the coefficient on the dummy variable indicating that the firm is registered with any of the three agencies smaller and statistically insignificant. When the three dummy variables indicating that the firm is registered with each agency are included at the same time, the inclusion of these control variables reduces the size of marginal effect on the dummy variable indicating that the firm has a TPIN, although it remains statistically significant. The point estimate suggests that firms that have a TPIN are about 10 percentage points more likely to say that corruption is a serious problem than other firms are. The coefficients on the other two registration variables remain statistically insignificant.

Methodology: Impact of firm characteristics on bribes during specific transactions.

The previous sub-section looked at how firm characteristics affected firm perceptions about corruption. Firms that had TPINs were more likely to say corruption was a problem than other firms. This section looks at one possible reason for this. It is possible that corrupt officials 
in areas unrelated to registration target registered firms during transactions-perhaps because being registered indicates that the firms are more sophisticated or better performing.

To see whether this is the case, we look at whether registered firms were more likely to have bribes requested during transactions with officials. The survey asked whether bribes were requested or expected when getting utility connections and during tax inspections. Although this is only a very partial list of potential interactions, it has the advantage that the transactions are narrowly defined and so should be similar for different firms. The question of how different factors affect requests for informal payments during these transactions is explored using the following equation:

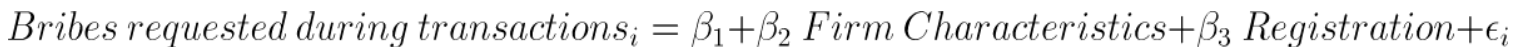

The dependent variables are dummy variables indicating whether bribes were requested or expected when getting water and power connections and during tax inspections. ${ }^{19}$ The independent variables are the same as in the previous sub-section. The error term is assumed to be normally distributed and the models are estimated using standard maximum likelihood estimation (i.e., probit estimation). Results are shown in Table 3. The table presents marginal effects for continuous variables and the effect of switching the dummy variable from 0 to 1 for dummy variables evaluated at the mean values for other variables.

\section{Empirical results for bribes requested during certain transactions}

Registration. The coefficients on the dummy variables are statistically insignificant in all cases but one. The coefficient on the dummy variable indicating that the firm is registered with PACRO is statistically significant and negative in the regression for getting a power connection. The coefficients on the other dummy variables are statistically insignificant in all regressions. ${ }^{20}$

\footnotetext{
${ }^{19}$ Although the survey asked about getting fixed telephone line connections, there were too few transactions for the model to converge.

${ }^{20}$ When the three variables are included separately (i.e., one registration variable at a time), the coefficients are all statistically insignificant in all cases but two. The first is the same as the one previously noted when all are included at the same time. The coefficient on the dummy variable indicating that the firm is registered with PACRO is statistically significant and negative in the regression for getting a power connection. When the other two dummies are omitted, the coefficient on the variable indicating that the firm has a TPIN is statistically significant and negative.
} 
Overall, this does not provide any support for the idea that firms that are registered are more likely to have bribes requested during transactions with the government than other firms are.

Other firm characteristics. For the most part, the coefficients on the other control variables are also statistically insignificant at conventional significance levels. Notably, although larger firms were more likely to report that corruption was a problem, they were no more likely to pay bribes than other firms were during the transactions that the survey asked about.

The coefficient on the dummy variables indicating that the firm was operating in urban areas were positive and statistically significant in two of the three transactions suggesting that urban firms are more likely to have bribes requested during transactions involving utility connections than rural firms. This could reflect either that these firms are more visible or that they have greater ability to pay than similar rural enterprises. The coefficient on the variable indicating the firm is more capital intensive is statistically significant in all cases, but is positive in two cases and negative in the other.

Finally, the coefficient on the dummy variable indicating that the firm is growing is positive in all three regressions, but is only statistically significant in one case. This might suggest that government officials are more likely to request bribes from firms that appear more successful. The results, however, are not strong in this respect and other results (e.g., for capital intensive or large firms) do not provide strong support for this hypothesis.

Methodology: Impact of firm characteristics on engaging in specific transactions.

Although registered firms do not appear any more likely to have bribes requested during specific transactions with government officials, it is possible that they might interact more frequently with government officials. If there are more likely to engage in transactions with the potential for corruption, the corruption might be a greater concern for them even if they are no more likely to need to pay bribes during these transactions. This sub-section looks at the likelihood that firms have on engaged in several transactions associated with corruption. The equation estimated is:

Firm engaged in transaction F $_{i}=\beta_{1}+\beta_{2}$ Firm Characteristics $+\beta_{3}$ Registration $+\epsilon_{i}$ 
The dependent variables are dummy variables indicating whether the firm got three types of utility connections (fixed-line telephone, power and water) and whether they were inspected by the tax authorities.

In addition, we also look at whether they engaged in other transactions that were asked about in the survey that might involve bribe payments but where bribe payments were not asked about specifically. The additional variables include three dummies indicating that the firm has a power connection, has a fixed line telephone connection, and has a public water connection. Although bribes can be associated with getting the connection, it is also possible that bribes might be requested at other times such as when there are outages or when repairs are needed. ${ }^{21}$ Similarly, bribes or informal payments can also be helpful in securing government contracts or sales. $^{22}$

The independent variables are the same as in the previous section. The error term is assumed to be normally distributed and the models are estimated using standard maximum likelihood estimation. Results are shown in Table 4 and Table 5.

\section{Empirical results for probability of engaging in transactions}

Registration. Even after controlling for other factors that might affect whether they have utility connections, apply for new connections, are inspected by the tax authorities, or sell to the government, firms that have operating licenses and TPINs than other firms are generally more likely to engage in transactions with the government than others are. The differences can be quite large. Firms that have TPINs were about 2 percentage points more likely to have applied for a fixed line phone, 6 percentage points more likely to have applied for a power connection, 5 percentage points more likely to apply for a water connection and were 1 percentage point more likely to have been inspected. Given that so few firms were involved with any of these transactions, these differences are relatively large (see Table 6). Similar results hold for firms that were registered with local government. In contrast, there was no evidence that firms

\footnotetext{
${ }^{21}$ During field interviews in Lusaka in 2007, several firm managers noted that small gifts or informal payments can help ensure that service is restored more quickly following power outages.

${ }^{22}$ Although the question was not asked in the ZBS, about 28 percent of firms that did business with the government in the 2007 Zambia Enterprise Survey reported that bribes were needed to secure government contracts.
} 
registered with PACRO were more likely to be involved in these transactions than other firms were after controlling for other things. One plausible explanation for why registered firms are more likely to engage in these transactions is that these firms are more sophisticated than other firms even after controlling for other things.

Other Firm Characteristics. The other variables are mostly consistent with the idea that larger, more sophisticated firms are more likely to engage in transactions with the government. Large firms are more likely to have power and water connections, to have applied for a power connection within the past two years, and to have been inspected by the tax authorities. Similarly, capital intensive firms are more likely to have engaged in all transactions, including selling to the government, and to have utility connections. Urban firms are generally more likely to have applied for utility connections and to have such connections. Faster-growing firms are also more likely to have applied for a water connection, more likely to have a power connection, and are more likely to have sold to the government. Finally, older firms are less likely to have utility connections and are less likely to have applied for them. They are, however, more likely to sell to the government.

\section{Conclusions}

This paper looks at whether registered microenterprises in Zambia are more affected by corruption than unregistered enterprises. Before controlling for other factors that affect how visible firms are to government officials such as size, capital intensity and location, firms that are registered are more likely to say that corruption is a serious problem than other firms. After controlling for these factors, however, firms that are registered with PACRO and that have operating licenses from the local authorities are no more likely to say that corruption is a problem than other firms are. This is not true for firms registered with the Zambia Revenue Authority - they are more likely to say that corruption is a problem even after controlling for other things that affect visibility.

The paper explores two possible reasons for why these firms might be more concerned about corruption than unregistered firms. One possibility is that corrupt bureaucrats involved in transactions unrelated to registration, such as getting utility connections, target registered firms. They might do this, for example, if they believe that registered firms are more profitable than 
other firms. There is little evidence that this is the case. After controlling for other things that might affect bribe demands, registered firms were no more likely to pay bribes during specific transactions than similar unregistered firms.

Although registered firms are no more likely to pay bribes during specific transactions, corruption might still be a greater concern for these firms if they are more likely to engage in transactions with the government. That is, the burden of corruption might be greater for registered firms not because they registered but because they are more likely to be involved in other transactions with the government. The results support this idea-registered firms are more likely to be involved in these transactions than unregistered firms. Since some of these transactions are voluntary and unrelated to registration, it is possible that corruption might not greatly discourage registration. 


\section{References}

ACT Watch. 2009. "Outlet Survey Report (Baseline). Republic of Zambia." ACT Watch: Lusaka, Zambia.

Buehn, Andreas, and Fredrich Schneider. Forthcoming. "Corruption and the Shadow Economy: Like Oil and Vinegar, like Water and Fire." International Tax and Public Finance.

Clarke, George R. G., Manju Kedia Shah, Marie Sheppard, Julliet Munro, and Roland Pearson. 2010. "The Profile and Productivity of Zambian Businesses." World Bank: Lusaka, Zambia.

Clarke, George R. G., and Lixin Colin Xu. 2004. "Privatization, Competition and Corruption: How Characteristics of Bribe Takers and Payers Affect Bribes To Utilities." Journal of Public Economics 88(9-10):2067-97.

de Soto, Hernando. 1988. The Other Path. New York: Basic Books.

Dreher, Axel, and Fredrich Schneider. 2010. "Corruption and the Shadow Economy: An Empirical Analysis." Public Choice 144(1-2):215-238.

Easterly, William. 2002. The Elusive Quest for Growth. Cambridge, MA: MIT Press.

Economics Association of Zambia. 2009. "Business Unusual: The Policy Implications for Zambia of the Global Economic Crisis." Economics Association of Zambia: Lusaka, Zambia.

Foreign Investment Advisory Service. 2004a. "Republic of Zambia: Administrative Barriers to Investment." International Finance Corporation and the World Bank: Washington DC.

-------. 2004b. "Republic of Zambia: Sectoral Study of the Effective Tax Burden." International Finance Corporation and the World Bank: Washington DC.

Friedman, Eric, Simon Johnson, Daniel Kaufmann, and Pablo Zoido-Lobaton. 2000. "Dodging the Grabbing Hand: The Determinants of Unofficial Activity in 69 Countries." Journal of Public Economics 76(3):459-493.

Gaviria, Alejandro. 2002. "Assessing the Effects of Corruption and Crime on Firm Performance: Evidence From Latin America." Emerging Markets Review 3(4):245-268.

Gonzalez, Alvaro, J. Ernesto Lopez-Cordova, and Elio E. Valladares. 2007. "The Incidence of Graft on Developing Country Firms." Policy Research Working Paper 4394. World Bank, Washington DC. 
Johnson, Simon, Daniel Kaufmann, John McMillan, and Christopher Woodruff. 2000. "Why Do Firms Hide? Bribes and Unofficial Activity After Communism." Journal of Public Economics 76(3):495-520.

May, J. W., W. Pyle, and P. M. Sommers. 2002. "Does Governance Explain Unofficial Activity?" Applied Economics Letters 9(8):537-539.

Melzer, Idina, Reut Agasi, and Harry Botha. 2009. "Demand Side Analysis of Access to Financial Services for Businesses in Zambia." Finmark Trust: Lusaka, Zambia.

Mendez, Fabio, and Facundo Sepulveda. 2007. "Corruption, Regulation Compliance and the Shadow Economy." University of Arkansas: Fayetteville, AR.

Patent and Companies Registration Office, 2009a. Frequently Asked Questions on Business Names. Retrieved 5-14-2009a, from Patent and Companies Registration Office web site: http://www.pacro.org.zm/index.php?option=com_content\&task=view\&id=38\&Itemid=.

Patent and Companies Registration Office, 2009b. Frequently Asked Questions on Companies. Retrieved 5-14-2009b, from Patent and Companies Registration Office web site: http://www.pacro.org.zm/index.php?option=com_content $\&$ task=view\&id=37\&Itemid=.

Perry, Guillermo E., William F. Maloney, Omar S. Arias, Pablo Fajnzylber, Andrew D. Mason, and Jaime Saavedra-Chanduvi. 2006. Informality: Exit and Exclusion. Washington DC: World Bank.

Regional Program on Enterprise Development, Africa Private Sector Group. 2004. "An Assessment of the Investment Climate in Zambia." Regional Program for Enterprise Development, World Bank: Washington DC.

Safavian, Mehnaz S., Douglas H. Graham, and Claudio Gonzalez-Vega. 2001. "Corruption and Microenterprises in Russia." World Development 29(7):1215-24.

Schneider, Fredrich, and Dominik Enste. 2000. "Shadow Economies: Size, Causes and Consequences." Journal of Economic Literature 38(1):77-114.

Schneider, Friedrich. 2005. "Shadow Economies Around the World: What Do We Really Know?" European Journal of Political Economy 21(3):598-642.

Schneider, Friedrich, and Robert Klinglmair. 2004. "Shadow Economies Around the World: What Do We Know?" Discussion Paper 1043. Institute for the Study of Labor (IZA), Bonn, Germany.

Smith, Philip. 1994. "Assessing the Size of the Underground Economy: the Canadian Statistical Perspectives." Canadian Economic Observer 11(10):16-33.

Svensson, Jakob. 2003. "Who Must Pay Bribes and How Much? Evidence From a Cross Section of Firms." Quarterly Journal of Economics 118(1):207-230. 
Times of Zambia. 2008. "Zambia: License Fees Still Low -- Mutati." Times of Zambia, August 4.

United Nations Conference on Trade and Development. 2003. "Investment Policy Review-Zambia." United Nations: New York, NY.

World Bank. 2003. Doing Business in 2004. Washington DC: World Bank.

Zambia Development Agency. 2009. "Procedures and Guidelines for Obtaining Investment Licence." Zambia Development Agency: Lusaka, Zambia.

Zambia Revenue Authority. 2004. "Income Tax (Amendment) Act 2004." Zambia Revenue Authority: Lusaka, Zambia.

-------. 2009a. "A Guide to TPIN Registration." Leaflet 12. Lusaka, Zambia.

Zambia Revenue Authority, 2009b. Getting Started in Business. Retrieved 5-18-2009b, from Zambia Revenue Authority web site: http://www.zra.org.za/starting_business.php. 


\section{Tables}

Table 1: Summary statistics for registered and unregistered MSMEs

\begin{tabular}{lccc}
\hline & All & Registered & Unregistered \\
\hline Number of workers & 4.6 & 5.3 & 4.5 \\
Age of firm & 11.1 & 7.7 & 11.3 \\
Firm employment is growing (dummy) & $26 \%$ & $32 \%$ & $26 \%$ \\
Firm is located in urban area (dummy) & $19 \%$ & $61 \%$ & $16 \%$ \\
Capital intensity (index) & 2.2 & 2.2 & 2.2 \\
Sector - Manufacturing (dummy) & $3 \%$ & $8 \%$ & $2 \%$ \\
Sector - Agriculture (dummy) & $70 \%$ & $30 \%$ & $73 \%$ \\
Sector - Retail and Wholesale Trade (dummy) & $22 \%$ & $41 \%$ & $21 \%$ \\
Sector - Other Services (dummy) & $4 \%$ & $19 \%$ & $3 \%$ \\
Sector - Other (dummy) & $0 \%$ & $1 \%$ & $0 \%$ \\
\hline
\end{tabular}

Source: Author's calculations based upon data from the Zambia Business Survey MSME survey.

Note: All variables are weighted means. Registered means registered with any agency

${ }^{a}$ The index variable is calculated as a sum of series of dummy variables indicating that the firm owns various types of capital equipment. There are: (i) motor vehicle for company use; (ii) fax machine; (iii) photocopier; (iv) cash register; (v) calculator; (vi) storage space for business; (vii) vault; (viii); credit card machine; (ix) factory machinery; (x) tractor; (xi) hammer mill; (xii) treadle pump; (xiii) oxen; (xiv) ox-cart; (xv) plough; (xvi) hoe. We experimented with various specifications including dropping some of the more minor pieces of equipment (calculator, oxen, ox-cart, plough and hoe) and, dividing them into capital that was agricultural and non-agricultural. Doing this did not appear to have a significant impact on either the statistical significance or sign on this variable or on the other main variables included in the analysis

Table 2: Effect of enterprise characteristics on perceptions about corruption.

\begin{tabular}{|c|c|c|c|c|}
\hline \multirow[b]{2}{*}{ Observations } & \multicolumn{4}{|c|}{$\begin{array}{l}\text { Corruption as a constraint on current operations } \\
\text { (index - high values mean greater constraint) }\end{array}$} \\
\hline & 3656 & 3656 & 3337 & 3337 \\
\hline Sector Dummies & No & No & Yes & Yes \\
\hline \multicolumn{5}{|l|}{ Registration Status } \\
\hline $\begin{array}{l}\text { Registered with any agency } \\
\text { (dummy) }\end{array}$ & $\begin{array}{l}0.218 * * * \\
(3.78)\end{array}$ & & $\begin{array}{l}-0.007 \\
(-0.10)\end{array}$ & \\
\hline $\begin{array}{l}\text { Registered with Zambia Revenue Authority } \\
\text { (dummy) }\end{array}$ & & $\begin{array}{l}0.458 * * * \\
(3.74)\end{array}$ & & $\begin{array}{c}0.300 * * \\
(2.24)\end{array}$ \\
\hline Registered with PACRO & & 0.045 & & -0.015 \\
\hline (dummy) & & $(0.44)$ & & $(-0.13)$ \\
\hline Has operating license with local government & & 0.036 & & -0.093 \\
\hline (dummy) & & $(0.46)$ & & $(-1.08)$ \\
\hline \multicolumn{5}{|l|}{ Firm Characteristics } \\
\hline $\begin{array}{l}\text { Workers } \\
\text { (natural log) }\end{array}$ & & & $\begin{array}{l}0.284 * * * \\
(5.08)\end{array}$ & $\begin{array}{l}0.284 * * * \\
(5.07)\end{array}$ \\
\hline $\begin{array}{l}\text { Workers Squared } \\
\text { (natural } \log \text { ) }\end{array}$ & & & $\begin{array}{l}-0.06 * * * \\
(-3.21)\end{array}$ & $\begin{array}{c}-0.06 * * * \\
(-3.22)\end{array}$ \\
\hline Urban & & & $0.306 * * *$ & $0.300 * * *$ \\
\hline (dummy) & & & $(6.42)$ & $(6.28)$ \\
\hline Capital intensity & & & $0.059 * * *$ & $0.055^{* * *}$ \\
\hline (index, high values mean more intensive) & & & $(4.44)$ & $(4.14)$ \\
\hline Age of firm & & & 0.012 & 0.013 \\
\hline (natural log) & & & $(0.61)$ & $(0.64)$ \\
\hline Firm employment is growing & & & -0.030 & -0.034 \\
\hline (dummy) & & & $(-0.63)$ & $(-0.71)$ \\
\hline Pseudo R-Squared & 0.00 & 0.00 & 0.01 & 0.01 \\
\hline
\end{tabular}

Source: Author's calculations based upon data from the Zambia Business Survey MSME survey.

$* * * * * *$ Statistically significant at a 1 percent, 5 percent, and 10 percent level 
Table 3: Probability that firm paid bribes during requests for connections and tax inspections

\begin{tabular}{|c|c|c|c|}
\hline & $\begin{array}{l}\text { Bribe requested } \\
\text { to get power } \\
\text { connection }\end{array}$ & $\begin{array}{l}\text { Bribe requested } \\
\text { to get water } \\
\text { connection }\end{array}$ & $\begin{array}{l}\text { Bribe requested } \\
\text { during tax } \\
\text { inspection }\end{array}$ \\
\hline Observations & 134 & 153 & 109 \\
\hline Sector Dummies & Yes & Yes & Yes \\
\hline \multicolumn{4}{|l|}{ Registration } \\
\hline $\begin{array}{l}\text { Registered with Zambia Revenue Authority } \\
\text { (dummy) }\end{array}$ & $\begin{array}{l}-0.079 \\
(-1.11)\end{array}$ & $\begin{array}{l}0.115 \\
(0.81)\end{array}$ & $\begin{array}{l}-0.071 \\
(-1.10)\end{array}$ \\
\hline Registered with PACRO & $-0.163 * * *$ & -0.098 & 0.062 \\
\hline (dummy) & $(-2.68)$ & $(-1.43)$ & $(0.99)$ \\
\hline Has operating or trade license with local government & 0.033 & -0.113 & -0.025 \\
\hline (dummy) & $(0.48)$ & $(-1.25)$ & $(-0.47)$ \\
\hline \multicolumn{4}{|l|}{ Firm Characteristics } \\
\hline Workers & 0.126 & -0.025 & -0.094 \\
\hline (natural log) & $(1.35)$ & $(-0.33)$ & $(-1.26)$ \\
\hline Workers Squared & -0.034 & 0.000 & 0.048 \\
\hline (natural $\log$ ) & $(-1.10)$ & $(0.02)$ & $(1.62)$ \\
\hline Age of firm & 0.057 & 0.037 & -0.036 \\
\hline (natural $\log$ ) & $(1.50)$ & $(0.98)$ & $(-1.24)$ \\
\hline Firm employment is growing & 0.106 & 0.017 & $0.144 * *$ \\
\hline (dummy) & $(1.57)$ & $(0.27)$ & $(2.21)$ \\
\hline Urban & $0.190 * * *$ & $0.148^{*}$ & -0.010 \\
\hline (dummy) & $(3.16)$ & $(1.93)$ & $(-0.21)$ \\
\hline Capital intensity & $0.042 * *$ & $0.080 * * *$ & $-0.043 * *$ \\
\hline (index, high values mean more capital intensive) & $(2.46)$ & $(5.44)$ & $(-2.27)$ \\
\hline Pseudo R-Squared & 0.29 & 0.39 & 0.18 \\
\hline
\end{tabular}

Source: Author's calculations based upon data from the Zambia Business Survey MSME survey.

Note: The table presents marginal effects for continuous variables and the effect of switching the dummy variable from 0 to 1 for dummy variables evaluated at the mean values for other variables.

$* * *, * * *$ Statistically significant at a 1 percent, 5 percent, and 10 percent level 
Table 4: Any new utility connections or tax inspections in past year.

\begin{tabular}{|c|c|c|c|c|}
\hline & $\begin{array}{l}\text { Got telephone } \\
\text { connection in } \\
\text { past year }\end{array}$ & $\begin{array}{l}\text { Got power } \\
\text { connection in } \\
\text { past } 2 \text { years }\end{array}$ & $\begin{array}{c}\text { Got water } \\
\text { connection in } \\
\text { past } 2 \text { years }\end{array}$ & $\begin{array}{c}\text { Any tax } \\
\text { inspection in } \\
\text { past year }\end{array}$ \\
\hline Observations & 4321 & 4288 & 4286 & 4280 \\
\hline Sector Dummies & Yes & Yes & Yes & Yes \\
\hline \multicolumn{5}{|l|}{ Registration } \\
\hline Registered with ZRA & $0.022 * * *$ & $0.056 * * *$ & $0.047 * *$ & $0.011 *$ \\
\hline (dummy) & $(3.11)$ & $(3.48)$ & $(2.20)$ & $(1.80)$ \\
\hline Registered with PACRO & 0.000 & 0.001 & -0.004 & $0.021 * * *$ \\
\hline (dummy) & $(0.03)$ & $(0.11)$ & $(-0.30)$ & $(3.16)$ \\
\hline Has operating license with local gov't. & $0.015 * * *$ & $0.054 * * *$ & $0.071 * * *$ & $0.058 * * *$ \\
\hline (dummy) & $(3.38)$ & $(5.07)$ & $(4.56)$ & $(7.30)$ \\
\hline \multicolumn{5}{|l|}{ Firm Characteristics } \\
\hline Workers & 0.003 & $0.014 * *$ & -0.013 & $0.006^{*}$ \\
\hline (natural log) & $(1.25)$ & $(2.13)$ & $(-1.47)$ & $(1.75)$ \\
\hline Workers Squared & -0.001 & $-0.004 *$ & 0.003 & -0.002 \\
\hline (natural log) & $(-0.93)$ & $(-1.69)$ & $(0.87)$ & $(-1.21)$ \\
\hline Age of firm & $-0.002 * *$ & $-0.011 * * *$ & $-0.016 * * *$ & -0.001 \\
\hline (natural $\log$ ) & $(-2.22)$ & $(-4.64)$ & $(-4.69)$ & $(-0.65)$ \\
\hline Firm employment is growing & 0.003 & 0.006 & $0.022 * * *$ & $0.006^{*}$ \\
\hline (dummy) & $(1.62)$ & $(1.11)$ & $(2.78)$ & $(1.81)$ \\
\hline Urban & $0.005 * *$ & $0.021 * * *$ & -0.002 & 0.001 \\
\hline (dummy) & $(2.51)$ & $(3.95)$ & $(-0.32)$ & $(0.44)$ \\
\hline Capital intensity & $0.001 * * *$ & $0.005 * * *$ & $0.008 * * *$ & $0.002 * * *$ \\
\hline (index, high values mean more capital) & $(2.80)$ & $(3.55)$ & $(4.31)$ & $(2.94)$ \\
\hline Pseudo R-Squared & 0.31 & 0.23 & 0.09 & 0.34 \\
\hline
\end{tabular}

Source: Author's calculations based upon data from the Zambia Business Survey MSME survey.

Note: The table presents marginal effects for continuous variables and the effect of switching the dummy variable from 0 to 1 for dummy variables evaluated at the mean values for other variables.

$* * * * * *$ Statistically significant at a 1 percent, 5 percent, and 10 percent level 
Table 5: Transactions with the Government

\begin{tabular}{|c|c|c|c|c|}
\hline & $\begin{array}{l}\text { Has Power } \\
\text { Connection }\end{array}$ & $\begin{array}{c}\text { Has Public Water } \\
\text { Connection }\end{array}$ & $\begin{array}{l}\text { Has Fixed Line } \\
\text { Telephone }\end{array}$ & $\begin{array}{l}\text { Sells to the } \\
\text { Government }\end{array}$ \\
\hline Observations & 4332 & 4292 & 4266 & 4330 \\
\hline Sector Dummies & Yes & Yes & Yes & Yes \\
\hline \multicolumn{5}{|l|}{ Registration } \\
\hline Registered with ZRA & $0.085 * * *$ & $0.054 * *$ & $0.005 * *$ & 0.001 \\
\hline (dummy) & $(3.67)$ & $(2.37)$ & $(2.52)$ & $(0.06)$ \\
\hline Registered with PACRO & 0.024 & -0.020 & 0.000 & 0.003 \\
\hline (dummy) & $(1.60)$ & $(-1.54)$ & $(0.44)$ & $(0.38)$ \\
\hline Has operating license with local gov't. & $0.114 * * *$ & $0.078 * * *$ & $0.008 * * *$ & 0.008 \\
\hline (dummy) & $(7.50)$ & $(5.04)$ & $(3.60)$ & $(1.00)$ \\
\hline \multicolumn{5}{|l|}{ Firm Characteristics } \\
\hline Workers & $0.025 * * *$ & $0.024 * *$ & 0.001 & 0.005 \\
\hline (natural $\log$ ) & $(2.83)$ & $(2.48)$ & $(1.01)$ & $(1.14)$ \\
\hline Workers Squared & $-0.006^{* *}$ & -0.004 & -0.000 & 0.000 \\
\hline (natural $\log$ ) & $(-1.99)$ & $(-1.14)$ & $(-0.62)$ & $(0.04)$ \\
\hline Age of firm & $-0.016 * * *$ & $-0.017 * * *$ & 0.000 & $0.004 * * *$ \\
\hline (natural log) & $(-4.98)$ & $(-4.71)$ & $(1.44)$ & $(2.70)$ \\
\hline Firm employment is growing & $0.020 * *$ & -0.008 & 0.001 & $0.006^{*}$ \\
\hline (dummy) & $(2.45)$ & $(-1.00)$ & $(1.42)$ & $(1.65)$ \\
\hline Urban & $0.066^{* * *}$ & $0.084 * * *$ & 0.001 & -0.002 \\
\hline (dummy) & $(8.28)$ & $(9.43)$ & $(1.11)$ & $(-0.44)$ \\
\hline Capital intensity & $0.009 * * *$ & $0.007 * * *$ & $0.001 * * *$ & $0.002 * *$ \\
\hline (index, high values mean more capital) & $(4.35)$ & $(3.06)$ & $(4.24)$ & $(2.21)$ \\
\hline Pseudo R-Squared & 0.319 & 0.208 & 0.48 & 0.105 \\
\hline
\end{tabular}

Source: Author's calculations based upon data from the Zambia Business Survey MSME survey.

Note: The table presents marginal effects for continuous variables and the effect of switching the dummy variable from 0 to 1 for dummy variables evaluated at the mean values for other variables.

$* * * * * *$ Statistically significant at a 1 percent, 5 percent, and 10 percent level

Table 6: Percent of firms completing transactions

\begin{tabular}{l|cc}
\hline & $\begin{array}{c}\text { Percent of firms that attempt to } \\
\text { complete transaction }\end{array}$ & $\begin{array}{c}\text { Percent that report bribe request } \\
\text { during transaction }\end{array}$ \\
\hline Get fixed line telephone & $0.7 \%$ & $17 \%$ \\
Get power connection & $3.1 \%$ & $16 \%$ \\
Get public water connection & $3.1 \%$ & $34 \%$ \\
Have tax inspection & $1.8 \%$ & $21 \%$ \\
\hline
\end{tabular}

Source: Author's calculations based upon data from the Zambia Business Survey MSME survey.

Note: All variables are weighted means. Utility connections are within past two years before survey. Tax inspections were in previous fiscal year. 